\title{
A Review Based on Low- and High-Stream Global Carbon Capture and Storage (CCS) Technology and Implementation Strategy
}

\author{
Abu Saleh Ahmed*, Md. Rezaur Rahman and Muhammad Khusairy Bin Bakri \\ Faculty of Engineering, Universiti Malaysia Sarawak, Jalan Datuk Mohammad Musa, 94300 \\ Kota Samarahan, Sarawak, Malaysia.
}

\begin{abstract}
Carbon capture and storage (CCS) is a method used to capture $\mathrm{CO}_{2}$ that is produced via the combustion of fossil fuels and then store it away from the atmosphere for a long time. The focus of CCS is on power generation and industrial sectors, mainly because they emit such a large volume of carbon dioxide that the capture and storage there will be the most beneficial. The most researched/developed ways to capture $\mathrm{CO}_{2}$ are pre-combustion capture, post-combustion capture, and oxyfuel combustion capture. Once the carbon dioxide is captured, it can either be stored underground or stored in the ocean. Source of $\mathrm{CO}_{2}$ seriously affecting our planet. The major factor in increased global warming comes from carbon dioxide emission. Coal fire power plants, cement/brick factories, oil refineries, natural gas wells, and transportation all emit $\mathrm{CO}_{2}$ from the burning of fossil fuels. Many countries are planning to set mandatory caps on $\mathrm{CO}_{2}$ emissions, causing companies to develop and test methods to mitigate their carbon footprint. This study focuses on the processes and techniques of CCS technology as well as challenges and policy concerns.
\end{abstract}

Keywords: Carbon; Capture; Storage; Technology; Analysis.

\section{Introduction}

Climate change and global warming triggered a global effort to reduce carbon dioxide concentration in the atmosphere. Carbon capture and storage (CCS) technology, also known as carbon capture and storage or carbon removal and sequestration, is the method of trapping and transporting waste carbon dioxide $\left(\mathrm{CO}_{2}\right)$ to a storage facility where it cannot be released into the atmosphere. Researchers developed lots of strategies and studies in findings and mitigate the carbon dioxide emission effects. At current, the most ongoing well-known development and mitigation strategy is called carbon capture and storage (CCS) technology. This strategy is crucial to achieving carbon dioxide reduction. Boot-Hardford et al. [1] identified that the carbon capture and storage technology permit the continuation of a fossil-fueled use power station, i.e. electricity generation and industrial combustion process while avoiding $90 \%$ carbon dioxide emission from reaching the atmosphere. Many manufacturing processes in Borneo, notably manufacturer for cement, iron, steel or natural gas treatment in Sarawak often contain carbon dioxide, which can be fitted with CCS technology. According to Offshore Engineer [2], Japan Oil, Gas and Metals National Corporation (JOGMEC), JX Nippon Oil \& Gas Exploration, and Petronas join venture in testing CCS technology at Malaysian Gas Fields to investigate the high amount of carbon dioxide (CO2) produced. CCS provides one of few strategies minimizing $\mathrm{CO}_{2}$, whereas currently the best energy-efficient technology. CCS technology

\footnotetext{
* Corresponding author. Tel.: +6082-583 299

E-mail address: asaleh@unimas.my

Manuscript History:

Received 24 March, 2021, Revised 20 April, 2021, Accepted 21 April, 2021, Published 30 April, 2021
}

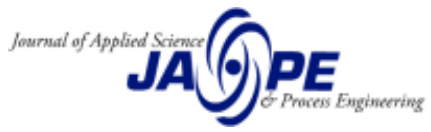


collected the $\mathrm{CO}_{2}$ preventing it from being releases to the atmosphere from large stationary sources, i.e. powerplant. The $\mathrm{CO}_{2}$ was compressed and transport to the location it was stored, i.e. deep aquifer, exhausted oil field or in the deep ocean. This technology is the opposite method to forestation and sequestration, whereas carbon dioxide is removed from the atmosphere. The top countries that have implemented CCS technology are Australia, Canada, Norway, the United Kingdom, and the United States. These five countries are noted for being pioneers in both supporting and deploying CCS technology, as well as those who have developed policies to build a business case for investing in CCS for deep decarbonization of power and industry. China, Denmark, Germany, Japan, and the Netherlands are among the most progressive countries in the world. In terms of CCS implementation, these countries have made substantial progress. They are currently in a position to use CCS to achieve their national climate change goals, but certain holes in regulation, strategy, and/or storage capability production must be filled before widespread implementation can take place. A group of twenty 'moderately performing' countries, many from the European Union, the Gulf Cooperation Council, and a few developed countries. This community has a significant opportunity to accelerate CCS deployment speeds, but they have yet to completely realise it. Finally, high-opportunity countries such as India, Indonesia, and Russia have low CCS-RI scores but depend heavily on CCS deployment. Without decisive action, meeting climate reduction targets and achieving future stability in a carbonconstrained environment would be unlikely. Therefore, with CCS technology, carbon dioxide was prevented to be released into the atmosphere [3]. In this study, different combustion technologies for $\mathrm{CO}_{2}$ capture and reduction strategies are discussed and reported.

\section{2. $\mathrm{CO}_{2}$ emissions}

Zoback and Gorelick [4] highest the carbon emission source potential risk, which mostly related to the petroleum refining process. The carbon emissions source also caused by chemical, iron, steel and cement industries. The main problem and the high risk of petroleum refining is its highest emission, which needed intensify procedure to capture the carbon for other application. It is also known that in the atmosphere, $\mathrm{CO}_{2}$ is amongst a very important component, whereas carbon dioxide was released through natural processes, i.e. respiration and volcano eruptions. It also emitted through human activities, i.e. deforestation, burning fossil fuels, and land-use changes. However, due to the fast and unfiltered emission, humans have forced an increase of $\mathrm{CO}_{2}$ concentration in the atmospheric more than a third, due to Industrial Revolution (IR). Human unemphatically "force" has caused huge long-lived climate change.

In 2010, the global $\mathrm{CO}_{2}$ emissions approached 30 gigatons (Gt). Approximately around $40 \%$ (12Gt) of the emission, which is emitted from the electricity generation sector to generate the heat needed to power steam-driven turbines, which involved fossil combustion fuels, i.e. oil, coal, and natural gas. Burning these fuels, increase $\mathrm{CO}_{2}$ production, which was the primary "greenhouse gas" heat-trapping that was responsible for global warming [5]. Furthermore, other types of gas and chemical, i.e. nitrogen and sulphur oxides were also responsible for various environmental impacts [5].

\section{Carbon capture and storage technology}

According to Smit [6], around $80 \%$ of $\mathrm{CO}_{2}$ was obtained from natural resources for enhanced oil recovery (EOR) in 2008, while the rest was from anthropogenic sources, i.e. coal gasification or gas processing plants in the United States. The high $\mathrm{CO}_{2}$ amount of energy conversion provided a high potential for it to be upgraded as chemicals and fuels. This increased the carbon dioxide price as it is needed to convert it into oil while reducing the $\mathrm{CO}_{2}$ emission into the atmosphere that causes the greenhouse effect. Besides, it can be used to replace $10 \%$ of materials for construction and building 
with carbonate minerals, whereas it is far more efficient to be used, and at the same time expected to reduce $\mathrm{CO}_{2}$ emissions [6].

Therefore, with the consideration of the fast depleted oil field, permanent $\mathrm{CO}_{2}$ storage is an attractive carbon storage options available at the current moment. However, the main scientific challenge and concern is the safety of $\mathrm{CO}_{2}$ storage sites, whereas does it remains for thousands of years. Therefore, monitoring, verification, and assessment of the technology's development of entire trapped underground $\mathrm{CO}_{2}$ remain essential. From the process, whereas the $\mathrm{CO}_{2}$ had been captured, it was required to transport to a suitable storage location. The efficient $\mathrm{CO}_{2}$ storage is by compression and usually super-critically dense into the fluid state [7]. It was also known the earn temperature and pressure carbon dioxide storage above the critical temperature and pressure, which was higher than $31.1{ }^{\circ} \mathrm{C}$ and the 73.9 bar, respectively [7]. With these conditions, the $\mathrm{CO}_{2}$ displays liquid with gas characteristic supercritical properties. Therefore, in carbon steel pipelines the $\mathrm{CO}_{2}$ were transported at high pressures, whereas not dissimilar to normal natural gas pipelines, or in ships if it needs to cross a great expanse of water. Particularly, in the US, there are already existing enhanced oil recovery (EOR) for $\mathrm{CO}_{2}$ pipelines at large scales, albeit primarily in sparsely inhabited areas. Depending on the rate and conditions, with consideration of the geothermal gradient, the temperature increases with depth. While the density of $\mathrm{CO}_{2}$ will increase with depth, as up to $800 \mathrm{~m}$ or greater, the injected $\mathrm{CO}_{2}$ was used in a dense supercritical state. For a power plant with CCS compared to a plant without CCS for secure storage, approximately $80-90 \%$ of the net result could reduce $\mathrm{CO}_{2}$ emissions to the atmosphere.

\section{4. $\mathrm{CO}_{2}$ fuels and chemical conversion technology}

For oil recovery, $\mathrm{CO}_{2}$ is one of the valuable resources. Therefore, carbon dioxide storage is useful to be implemented. In the United States, enhanced oil recovery (EOR), which is about $80 \%$ of $\mathrm{CO}_{2}$ was obtained from natural resources, while the rest was from anthropogenic sources, i.e. gas processing plants and coal gasification [6]. Under high amount energy conversion, the $\mathrm{CO}_{2}$ can be upgraded to fuels and chemicals. This causes increase on carbon dioxide price, whereas it was useful to be converted into oil, while reducing the emission of $\mathrm{CO}_{2}$ into the atmosphere, which reduces greenhouse effect. In addition, almost $10 \%$ of the $\mathrm{CO}_{2}$ can be used in construction and building materials, especially with carbonate minerals, which was efficient at the same time, as it also reduces $\mathrm{CO}_{2}$ emissions.

\section{Main techniques of $\mathrm{CO}_{2}$ capture}

To capture carbon dioxide, three techniques can be used [8], which was flue gas separation, oxy-fuel combustion and pre-combustion. Most of these techniques were used dependable on the sources, process, applications and environments.

\subsection{Flue gas separation}

The first method is post-combustion method [8], whereas the bubbling gas separated the $\mathrm{CO}_{2}$ from the flue gas of the power station, while a liquid solvent (i.e. ammonia) absorber column packed with that preferentially take out the $\mathrm{CO}_{2}$. It was one of the most used techniques, whereas in the absorber column, the chemicals become saturated, as a superheated stream around $120^{\circ} \mathrm{C}$ was passed through it. This releases $\mathrm{CO}_{2}$ from the trapped before transported elsewhere for storage. Without the two-step process, more experimental methods required to scrub $\mathrm{CO}_{2}$ from flue gas, i.e. using seawater to absorb the gas, while for long-term storage returning the mixture to the ocean. The technology is well-understood and is currently in use in other industrial applications, though not on the same scale as a commercial-scale power plant. Since current fossil fuel power plants can be retrofitted to use CCS

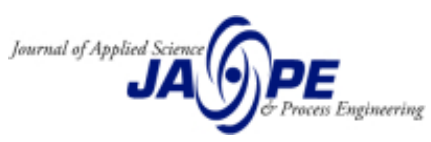


technology in this configuration, post-combustion capture is the most common in science. The fundamental reaction for $\mathrm{CO}_{2}$ absorbent is monoethanolamide (MEA) as shown in equation (1). However, at the current moment, most of these methods have proved to be less efficient and not reliable.

$$
\mathrm{C}_{2} \mathrm{H}_{4} \mathrm{OHNH}_{2}+\mathrm{H}_{2} \mathrm{O}+\mathrm{CO}_{2} \leftarrow \mathrm{C}_{2} \mathrm{H}_{4} \mathrm{OHNH}_{3}{ }^{+}+\mathrm{HCO}_{3}{ }^{-}
$$

\subsection{Oxy-fuel combustion}

Oxy-fuel combustion is the second method. Instead of burning in the air, the fuel is burnt in oxygen. Cooled flue gas is recirculated and pumped into the combustion chamber to keep the flame temperatures down to those used in traditional combustion. The flue gas primarily consists of carbon dioxide and water vapour, with the latter condensing as it cools. As a result, a nearly pure carbon dioxide stream will be shipped and deposited at the sequestration site. Depending on the fuel and the excess air amount, the carbon content is necessary for the combustion process, whereas fossil fuel, i.e. oil, coal, and natural gas was combusted in air, the $\mathrm{CO}_{2}$ fraction in the flue gas ranges from $3-15 \%$. By physical or chemical means, the $\mathrm{CO}_{2}$ separation from the rest of the flue gases, which was mostly $\mathrm{N}_{2}$ was energy-intensive and capitalize. Therefore, the most alternative way was to burn the fossil fuel in enriched or pure oxygen. In addition, the flue gas would mostly content $\mathrm{CO}_{2}$ and $\mathrm{H}_{2} \mathrm{O}$.

To control the flame temperature, the flue gas part needed to be recycled into the combustion chamber. Water vapour was readily condensed, the $\mathrm{CO}_{2}$ was compressed and piped directly to the storage site from the non-recycled flue gas. This forced the separation process to shift from the flue gas to the intake air, whereas one must separate oxygen from the nitrogen of the air. About $15 \%$ power plant's electric output was consumed by the air separation unit (ASU), which require an increase in fossil fuel commensurate to be consumed for achieving high rated plant electric output. In the ASU, the air was separated into liquid oxygen with other gaseous i.e. nitrogen and argon, while other minor ingredients of air. It was then saleable by oxyfuel plant products. Pilot-scale studies show that the method of capturing $\mathrm{CO}_{2}$ by oxyfuel method was retrofitted to existing pulverized coal (PC) plants [9].

\subsection{Pre-combustion}

The last method is pre-combustion. Normally, this method was applied to combined coalgasification cycle power plants. Pre-combustion technology is commonly used in the fertiliser, chemical, and gaseous fuel $(\mathrm{H} 2, \mathrm{CH} 4)$ industries. The carbon fuel is partly oxidised in these situations, such as in a gasifier. To produce synthetic gas, the coal was gasified, which was made from carbon monoxide and hydrogen. It was later reacted with water to produce $\mathrm{CO}_{2}$, which was also captured with more hydrogen. The hydrogen was diverted to a turbine and burned to produce electricity. Otherwise, some of these gases were bled off to feed cars hydrogen fuel cells. Capturing $\mathrm{CO}_{2}$ before combustion provides some advantages. The $\mathrm{CO}_{2}$ was not yet diluted at the first part through air combustion. The second part of the $\mathrm{CO}_{2}$ containing stream was usually at elevated pressure. Therefore, further wellorganized separation methods were applied, such as using pressure-swing-absorption in physical solvents, i.e. methanol or polyethylene glycol (which was also called through their commercial brands Rectisol and Selexol). In coal gasification combined cycle (IGCC) power plants, pre-combustion capture was usually used. However, it was unproven whether pre-combustion capture is preferable to the standard post-combustion capture for the case of using natural gas [9]. In the case of coal, pretreatment involves a process of gasification in a low-oxygen gasifier forming a syngas consisting mainly of $\mathrm{CO}$ and $\mathrm{H}_{2}$ and is mainly free from other polluting gases equation (2).

Gasification worldwide facilities exist today do not generate electricity, however its synthesis gas and other various coal gasification by-products. In these facilities, after the gasification stage from 
the other gases, $\mathrm{CO}_{2}$ was separated, i.e. methane, hydrogen or a mix of carbon monoxide and hydrogen. The hydrogen or synthesis gas are used as a fuel or for chemical raw material, e.g. for liquid fuel manufacturing or ammonia synthesis. For dry ice manufacturing, carbonated beverages, and enhanced oil recovery (EOR), $\mathrm{CO}_{2}$ was used as a chemical raw material. For instance, near Beulah, North Dakota, the Great Plains Synfuel Plant gasifies 16,326 metric tons per day of lignite coal into 3.5 million standard cubic meters per day of combustible syngas, and close to 7 million standard cubic meters of $\mathrm{CO}_{2}$. The $\mathrm{CO}_{2}$ part was captured by a physical solvent based on methanol. The captured $\mathrm{CO}_{2}$ was compressed, which produced around 2.7 million standard cubic meters per day were piped over a $325 \mathrm{~km}$ distance to the Weyburn oil field in Saskatchewan, whereas the $\mathrm{CO}_{2}$ was used for enhanced oil recovery [1].

\section{Comparison of Different Combustion Technologies for $\mathrm{CO}_{2}$ Capture}

Table 1 compares the three $\mathrm{CO}_{2}$ capture technologies, whereas the pre-combustion was mainly applied to coal-gasification plants, while post-combustion and oxyfuel combustion were applied to both coal-fired and gas-fired plants. Post-combustion processing was probably the most sophisticated method for $\mathrm{CO}_{2}$ capture $[10,11]$.

Table 1. Different $\mathrm{CO}_{2}$ capture technologies advantages and disadvantages $[10,11]$.

\begin{tabular}{|c|c|c|c|}
\hline $\begin{array}{l}\text { Capture } \\
\text { process }\end{array}$ & $\begin{array}{c}\text { Application } \\
\text { area }\end{array}$ & Advantages & Disadvantages \\
\hline $\begin{array}{c}\text { Post- } \\
\text { combustion }\end{array}$ & $\begin{array}{l}\text { Coal-fired } \\
\text { and gas- } \\
\text { fired plants }\end{array}$ & $\begin{array}{l}\text { Technology is more mature than } \\
\text { other alternatives, which can easily } \\
\text { retrofit into existing plants. }\end{array}$ & $\begin{array}{l}\text { Low } \mathrm{CO}_{2} \text { concentration affects } \\
\text { the capture efficiency }\end{array}$ \\
\hline $\begin{array}{c}\text { Pre- } \\
\text { combustion }\end{array}$ & $\begin{array}{l}\text { Coal- } \\
\text { gasification } \\
\text { plants }\end{array}$ & $\begin{array}{l}\text { High } \mathrm{CO}_{2} \text { concentration enhance } \\
\text { sorption efficiency, which was fully } \\
\text { developed technology, commercially } \\
\text { deployed at the required scale in } \\
\text { some industrial sectors and provide } \\
\text { an opportunity for retrofit to existing } \\
\text { plant }\end{array}$ & $\begin{array}{l}\text { Temperature associated heat } \\
\text { transfer problem and } \\
\text { efficiency decay issues } \\
\text { associated with the use of } \\
\text { hydrogen-rich gas turbine } \\
\text { fuel. High parasitic power } \\
\text { requirement for sorbent } \\
\text { regeneration. Inadequate } \\
\text { experience due to few } \\
\text { gasification plants currently } \\
\text { operated in the market. High } \\
\text { capital and operating costs for } \\
\text { current sorption } \\
\text { Systems. }\end{array}$ \\
\hline $\begin{array}{c}\text { Oxyfuel } \\
\text { combustion }\end{array}$ & $\begin{array}{l}\text { Coal-fired } \\
\text { and gas- } \\
\text { fired plants }\end{array}$ & $\begin{array}{c}\text { Very high } \mathrm{CO}_{2} \text { concentration } \\
\text { enhances absorption efficiency. } \\
\text { Mature air separation technologies } \\
\text { available. Reduced volume of gas to } \\
\text { be treated. Hence required smaller } \\
\text { boiler and other equipment }\end{array}$ & $\begin{array}{c}\text { High-efficiency drops and } \\
\text { energy penalty, while cryogenic } \\
\mathrm{O}_{2} \text { production was costly and } \\
\text { corrosion problem may also } \\
\text { arise }\end{array}$ \\
\hline $\begin{array}{l}\text { Chemical } \\
\text { looping } \\
\text { combustion }\end{array}$ & $\begin{array}{l}\text { Coal- } \\
\text { gasification } \\
\text { plants }\end{array}$ & $\begin{array}{l}\mathrm{CO}_{2} \text { was the main combustion } \\
\text { product, which remains unmixed } \\
\text { with } \mathrm{N} 2 \text {. Thus, avoiding energy } \\
\text { intensive air separation }\end{array}$ & $\begin{array}{c}\text { The process is still under } \\
\text { development and inadequate } \\
\text { large-scale operation experience }\end{array}$ \\
\hline
\end{tabular}




\section{0 $\mathrm{CO}_{2}$ separation technologies}

$\mathrm{CO}_{2}$ key technology for the isolation was used to separate $\mathrm{CO}_{2}$ from the flue/fuel gas supply prior to transport. Advanced technologies such as wet scrubber, dry regenerative sorbents, membranes, cryogenics, pressure and temperature swing adsorption, and other advanced concepts have been developed.

\subsection{Absorption}

The liquid substance was used to isolate the $\mathrm{CO}_{2}$ from the flue gas. The sorbent was regenerated by a stripping or regenerative cycle through heating and/or depressurization. This cycle was the most advanced form of $\mathrm{CO}_{2}$ separation [12]. According to CQ Press [13], the high absorption capacity was at 490 per cent of sorbents were regenerated by heating and/or depressurization. This was the most advanced method for $\mathrm{CO}_{2}$ separation [14].

\subsection{Adsorption}

A solid sorbent was used to bind $\mathrm{CO}_{2}$ to its surfaces. Large specific surface area, high selectivity and high regenerative capacity were the main criteria for sorbent selection [15]. Typical sorbents include molecular sieves, activated carbon, zeolites, calcium oxides, hydrothalcites and zirconate lithium. Adsorbed $\mathrm{CO}_{2}$ was extracted by spinning the pressure (PSA) or the temperature (TSA) of the $\mathrm{CO}_{2}$-saturated sorbent device. PSA was a commercially available technology for the recovery of $\mathrm{CO}_{2}$ from power plants that were efficiency more than $85 \%$ [16].

\subsection{Chemical looping combustion}

Adánez et al. [17] noticed that help inert materials may be used to improve the output of metal oxides, but the choice of inert materials would rely on the kind of metal oxide used. Li et al. [18] have been experimentally testing the viability of chemical looping in a boiler with the configuration of two intertwined fluid beds. This research has recently been tested by Lyngfelt [19]. Both Adanez et al. [17] and Lyngfelt [19] have noticed that this method is a very good technique for $\mathrm{CO}_{2}$ capture. Erlach et al. [20] contrasted the $\mathrm{CO}_{2}$ isolation of the IGCC by pre-combustion with that of the chemical loop combustion and observed that the net plant output was $2.8 \%$ greater than the previous case.

\subsection{Membrane separation}

Membranes should be used to enable $\mathrm{CO}_{2}$ to flow through while removing other components of the flue gas. The most important part of this process was a membrane made of a thin selective layer composite polymer, while it was bonded to form a thicker, non-selective and low-cost layer that provides mechanical support for the membrane [1]. This process was often used to isolate other gasses such as $\mathrm{O}_{2}$ from $\mathrm{N}_{2}$, and $\mathrm{CO}_{2}$ from natural gas. Through designing high- performance membranes, Riahi et al. [21] obtained a $\mathrm{CO}_{2}$ separation level of $82 \%$ to $88 \%$. The ceramic, metallic, and polymeric membranes creation for membrane diffusion could allow membranes considerably more effective for $\mathrm{CO}_{2}$ separation than liquid absorption processes [22]. Brunetti et al. [23] performed a general existing membrane-based $\mathrm{CO}_{2}$ separation technology analysis and contrasted it to other adsorption and cryogenic separation technologies. It turned out that the efficiency of the membrane device is greatly influenced by flue gas pressures, such as low $\mathrm{CO}_{2}$ concentration and friction, which are the key obstacles to the implementation of this technology. Furthermore, Bernardo et al. [24] have reported that while there are major advances in gas separation membrane systems, they were still far from understanding the promise of this technology. 


\subsection{Hydrate-based separation}

Hydrate-based $\mathrm{CO} 2$ isolation is a modern process from which the $\mathrm{CO}_{2}$-containing waste gas is subjected to water under high pressure creating hydrates. The $\mathrm{CO}_{2}$ in the exhaust gas is specifically included in the hydrate cages and is isolated from other gases. The mechanism is focused on variations in the phase balance of $\mathrm{CO}_{2}$ with other gases, where $\mathrm{CO} 2$ can form hydrates more easily than other gases, such as $\mathrm{N}_{2}$ [25]. This technique has the benefit of a limited energy penalty (6-8\%) and the energy usage of hydrate capture of $\mathrm{CO}_{2}$ may be as low as $0.57 \mathrm{kWh} / \mathrm{kg}-\mathrm{CO}_{2}$, improving the rate of hydrate formation and rising hydrate pressure will increase the performance of $\mathrm{CO}_{2}$ capture.

\subsection{Cryogenic distillation}

Cryogenic distillation was a method of gas extraction by way of distillation at extremely low temperature and extreme pressure. It is identical to many modern distillation methods that used to isolate gaseous fluid components (due to their varying boiling points) from liquids [26]. For $\mathrm{CO}_{2}$ isolation, flue gas comprising $\mathrm{CO}_{2}$ was cooled to $\mathrm{DE}$ sublimation temperature from 100 to 135, and then the solidified $\mathrm{CO}_{2}$ was isolated from other light gasses and compressed to a maximum pressure of 100 to 200 ambient pressure [27]. The sum of $\mathrm{CO}_{2}$ extracted were around $90-95 \%$ of the flue gas. Since the distillation was carried out at exceptionally low temperature and heavy intensity, an energyconsuming procedure was calculated to be $600-660 \mathrm{kWh}$ per ton of $\mathrm{CO}_{2}$ obtained in liquid form [28].

\section{Mitigation global climate change approaches}

Multiple approaches were seen and implemented by various countries to decrease their $\mathrm{CO}_{2}$ emissions, including enhancing energy quality and encouraging energy conservation. It also increases the usage of low-carbon resources, i.e. natural gas, hydrogen or nuclear oil. While introducing sustainable energies, i.e. solar, wind, hydropower and bioenergy. Other small countries tying to implemented geoengineering methods, e.g. reforestation and reforestation. Table 2 contrasts the fields of use, the benefits and disadvantages of these various methods. Many of these solutions tackle the elimination of source pollution, such as renewable energies, clean power technology, while some discuss demand-side control, i.e. energy efficiency. Every solution has its own benefits and disadvantages that would assess its applicability. It was doubtful that a single solution or policy was achieved with the IPCC $\mathrm{CO}_{2}$ reduction goal of $50-85 \%$ from the year 2000 level by the year 2050 . Which was so comprehensive set of $\mathrm{CO}_{2}$ emission mitigation strategies needs to be established with consideration of various methods.

CCS would minimize the $\mathrm{CO}_{2}$ pollution by 85 to $90 \%$ from broad point emission sources, i.e. electricity generating systems and energy-intensive emitters, e.g. cement kiln plants. Through this method, $\mathrm{CO}_{2}$ was first collected from flue/fuel emissions, isolated from the sorbent, shipped and then either processed indefinitely or reused industrially. The CCS requires a range of techniques, including numerous methods for collecting, extracting, shipping, processing and tracking $\mathrm{CO}_{2}$, which were addressed separately in the following pages [29].

\section{CCS characteristics}

$\mathrm{CO}_{2}$ capture can be applied to large point sources. The $\mathrm{CO}_{2}$ would then be compressed and transported for storage in geological formations, in the ocean, in mineral carbonates or for use in industrial processes. Significant sources of $\mathrm{CO}_{2}$ include massive fossil fuel or biomass power stations, big $\mathrm{CO}_{2}$ emitting factories, natural gas processing, synthetic fuel stations and fossil fuel-based hydrogen manufacturing plants. Potential physical storage strategies are geological storage [30]. 
Table 2. $\mathrm{CO}_{2}$ reduction strategies summary.

\begin{tabular}{|c|c|c|c|}
\hline Strategy & $\begin{array}{l}\text { Application } \\
\text { area/sector }\end{array}$ & Advantages & Limitations \\
\hline $\begin{array}{l}\text { Enhance energy } \\
\text { efficiency and } \\
\text { energy } \\
\text { conservation }\end{array}$ & $\begin{array}{l}\text { Applied mainly in } \\
\text { commercial and } \\
\text { industrial buildings. }\end{array}$ & $\begin{array}{c}\text { Energy-saving from } \\
10 \% \text { to } 20 \% \text { easily } \\
\text { achievable. }\end{array}$ & $\begin{array}{l}\text { May involve extensive } \\
\text { capital investment for } \\
\text { installation of } \\
\text { the energy-saving device. }\end{array}$ \\
\hline $\begin{array}{l}\text { Increase usage of } \\
\text { clean fuels }\end{array}$ & $\begin{array}{l}\text { Substitution of coal by } \\
\text { natural gas for power } \\
\text { generation. }\end{array}$ & $\begin{array}{l}\text { Natural gas emits } 40- \\
50 \% \text { less } \mathrm{CO}_{2} \text { than } \\
\text { coal due to its lower } \\
\text { carbon content and } \\
\text { higher combustion } \\
\text { efficiency; cleaner } \\
\text { exhaust gas (lower } \\
\text { particulates and } \\
\text { sulfur dioxide } \\
\text { emissions). }\end{array}$ & $\begin{array}{c}\text { Higher fuel cost for } \\
\text { conventional natural gas. } \\
\text { The comparable cost for } \\
\text { shale gas. }\end{array}$ \\
\hline $\begin{array}{c}\text { Adopt clean coal } \\
\text { technologies }\end{array}$ & $\begin{array}{c}\text { Integrated gasification } \\
\text { combined cycle (IGCC), } \\
\text { pressurized fluidized bed } \\
\text { combustor (PFBC) etc. to } \\
\text { replace conventional } \\
\text { combustion. }\end{array}$ & $\begin{array}{l}\text { Allow the use of coal } \\
\text { with lower emissions } \\
\text { of air pollutants. }\end{array}$ & $\begin{array}{l}\text { Significant investment } \\
\text { needed to roll out } \\
\text { technologies widely. }\end{array}$ \\
\hline $\begin{array}{c}\text { Use of renewable } \\
\text { energy }\end{array}$ & $\begin{array}{c}\text { Hydro, solar (thermal), } \\
\text { wind power, and biofuels } \\
\text { highly developed. }\end{array}$ & $\begin{array}{l}\text { Use of local natural } \\
\text { resources; no or low } \\
\text { greenhouse and toxic } \\
\text { gas emissions. }\end{array}$ & $\begin{array}{l}\text { Applicability may depend } \\
\text { on local resources } \\
\text { availability and cost. Power } \\
\text { from solar, wind, marine } \\
\text { etc. are intermittent and } \\
\text { associated technologies are } \\
\text { not mature; most current } \\
\text { renewable energies are } \\
\text { more costly than } \\
\text { conventional energy. } \\
\end{array}$ \\
\hline $\begin{array}{l}\text { Development of } \\
\text { nuclear power }\end{array}$ & $\begin{array}{c}\text { Nuclear fission adopted } \\
\text { mainly in the US, France, } \\
\text { Japan, Russia and China. } \\
\text { Nuclear fusion still in the } \\
\text { research and } \\
\text { development phase. }\end{array}$ & $\begin{array}{c}\text { No air pollutant and } \\
\text { greenhouse gas } \\
\text { emissions. }\end{array}$ & $\begin{array}{c}\text { Usage is controversial; the } \\
\text { development of the world's } \\
\text { nuclear power is hindered } \\
\text { due to the Fukushima } \\
\text { Nuclear Accident in } 2011 \text {, } \\
\text { e.g. Germany will phase } \\
\text { out all its nuclear power } \\
\text { by } 2022 \text {. }\end{array}$ \\
\hline $\begin{array}{l}\text { Adopt clean coal } \\
\text { technologies }\end{array}$ & $\begin{array}{c}\text { Integrated gasification } \\
\text { combined cycle (IGCC), } \\
\text { pressurized fluidized bed } \\
\text { combustor (PFBC) etc. to } \\
\text { replace conventional } \\
\text { combustion. }\end{array}$ & $\begin{array}{l}\text { Allow the use of coal } \\
\text { with lower emissions } \\
\text { of air pollutants. }\end{array}$ & $\begin{array}{l}\text { Significant investment } \\
\text { needed to roll out } \\
\text { technologies widely. }\end{array}$ \\
\hline
\end{tabular}


Table 3. Method or industrial activity profile of large stationary $\mathrm{CO}_{2}$, sources worldwide with pollution of more than 0.1 million tons of $\mathrm{CO}_{2},\left(\mathrm{MtCO}_{2}\right)$ per year [30].

\begin{tabular}{|c|c|c|}
\hline Processes & Number of Sources & Emissions \\
\hline Fossil fuels & 4,942 & 10,539 \\
\hline Power & 1,175 & 932 \\
\hline Cement production & 638 & 798 \\
\hline Refineries & 269 & 646 \\
\hline Iron and steel industry & 470 & 379 \\
\hline Petrochemical industry & Not available & 50 \\
\hline Oil and gas processing & 90 & 33 \\
\hline Other sources & & \\
\hline Biomass & 303 & 91 \\
\hline Bioethanol and bionenergy & 7,887 & 13,466 \\
\hline Total & &
\end{tabular}

The substantial reduction of emissions to the atmosphere through CCS depends on the $\mathrm{CO}_{2}$ captured fraction, the increased production of $\mathrm{CO}_{2}$ resulting from the loss of overall efficiency of power plants or industrial processes due to the additional energy required for capture, transport and storage, any transport leakage and the long-term retention of the fraction of $\mathrm{CO}_{2}$. Available $\mathrm{CCS}$ technology captures around $85-95 \%$ of the $\mathrm{CO}_{2}$ produced in the capture plant. A power plant equipped with a CCS system with access to geological or ocean storage would need approximately 10 to 40 per cent, which is four-time more energy than a CCS equivalent power plant, whereas most of it was for capture and compress. The net result for secure storage was that a CCS power plant could reduce $\mathrm{CO}_{2}$ emissions to the atmosphere by approximately $80-90 \%$ compared to a CCS-free plant. To the extent that leakage could occur from a storage reservoir, the retained fraction is defined as the fraction of the cumulative amount of $\mathrm{CO} 2$ injected that is retained over a specified period. CCS plants with mineral carbonate storage would need $60-180 \%$ more energy than a CCS comparable device [30].

\section{Advantages and disadvantages}

According to Pires et al. [31], the CCS technology consist of three main processes namely carbon dioxide capture, carbon dioxide transport and carbon dioxide storage, which was very costly to be implemented, thus become limited. There was also a need to enhance the process application and performance so that the technology can be applied. The initial startup of this technology would require huge capital expenditure, thus additional incentives from the government are required to reduce the investment effort. Therefore, it was suggested that this technology be incentivized or government funding is available for the initial startup of this technology in the respective country.

The uncertainty that prevent CCS investment are the national regulations about storage. Politicians feel uncomfortable in taking decisions, whereas the safety issue was still unresolved. With the large-scale of the projects, it would require an authorization process to successfully mitigate the carbon emission [32]. Therefore, it was recommended that the associated risk regarding the project be informed to the public for ease of implementation. The public need to be well informed so that they would be able to influence the policies decision. The public intervention may expedite the implementation of the CCS due to the pressure it put on the politician and decision-makers [33]. The safety aspects would depend on the technology being used and the location of the storage of the $\mathrm{CO}_{2}$.

According to van Alphen et al. [34], there are six conditions highlighted by the public to support the implementation of CCS; safety, temporality and partiality, financial stimuli, simplicity, cooperation \& commitment, and open communication. CCS should be safe for human and the environment. Leakage of the $\mathrm{CO}_{2}$ from the reservoir will pose the largest risk and consequences. The 
second condition, temporality and partiality mean that CCS should only be a temporary solution to the climate change problem as it is deemed to be unsustainable. The third condition, financial stimuli refer to the incentives to support investment in the CCS. The fourth condition, simplicity prohibit the project to be linked to other products such as hydrogen or coal bed methane due to the view the CCS by itself is already complex. The fifth condition is the needs for cooperation and commitment between different sectors to ensure that the project is successful and implementable. The final condition is open communication about CCS to the public to maintain public acceptance. The implementation plan for CCS should include all conditions that have been suggested to ensure CCS technology can be implemented.

There is a plan on transporting the carbon dioxide as it is the best plan of using this method to reduce the cost of using the CCS. This is where the research of Leung et al., [29], stated that the pipelines are the most viable method for onshore transport of high volume of $\mathrm{CO}_{2}$ through long distances as CCS would likely involve when widely deployed. Pipelines are also the most efficient way for $\mathrm{CO}_{2}$ transport when the source of $\mathrm{CO}_{2}$ is a power plant which lifetime is longer than 23 years. For a shorter period, road and rail tankers are more competitive. The cost of transport varies considerably with the regional economic situation. A cost analysis in China shows that for a mass flow of 4000 tons of $\mathrm{CO}_{2} /$ day the use of ship tankers will cost $7.48 \mathrm{USD} /$ ton $\mathrm{CO}_{2}$ compared with 12.64 $\mathrm{USD} /$ ton $\mathrm{CO}_{2}$ for railway tankers and $7.05 \mathrm{USD} /$ ton $\mathrm{CO} 2$ for $300 \mathrm{~km}$ pipelines.

For commercial-scale CCS projects, an extensive network of $\mathrm{CO}_{2}$ pipelines needs to be developed. An integrated network, where different sources will merge for their final transport to the storage areas, can reduce the total pipeline's length by $25 \%$, but it will require that all sources produce $\mathrm{CO} 2$ stream with the same quality; pressure before being combined. When the flow managed through a network of pipelines increases there is an exponential decrease in the cost of transport; models highlight that the cost for transporting $\mathrm{CO}_{2}$ along a $1000 \mathrm{~km}$ pipeline is around $8 \mathrm{USD} /$ ton for a mass flow of $25 \mathrm{MtCO}_{2} /$ year with a further reduction down to $5 \mathrm{USD} /$ ton if the flow increases to 200 $\mathrm{MtCO}_{2} /$ year. Further cost saving may be achieved from the reuse of existing gas pipelines, but their suitability is to be verified [35]. One of the biggest uncertainties is the effects on the pipelines' integrity of long-term exposure to $\mathrm{CO}_{2}$ fluxes in terms of corrosion and potential brittle fractures propagation due to the sharp cooling of the pipelines in case of leak of supercritical $\mathrm{CO}_{2}$. The pipelines must be periodically monitored to assess their integrity and an accurate fiscal metering system is to be in place to assure the quantification of the stored fluxes. The equipment used for gas/oil pipelines needs to be modified to withstand the challenging environment experienced inside a $\mathrm{CO}_{2}$ pipeline. Poor lubrication capacity of $\mathrm{CO}_{2}$, high chemical reactivity and high pressure may all affect the performance of both monitoring and metering equipment.

In order to meet the GHG emission reduction target, a range of complementary technological approaches, including the improvement of energy efficiency and conservation, the adoption of clean fuels and clean coal technologies, the development of renewable energy and the implementation of CCS, have been considered by different countries in their own circumstances. It is noted that CCS comprises a portfolio of technologies that can significantly reduce $\mathrm{CO}_{2}$ emissions, but CCS has yet to be widely deployed. This paper discussed numerous techniques and problems relevant to $\mathrm{CO}_{2}$ detection, isolation, distribution, storage and tracking. The application of different $\mathrm{CO}_{2}$ capture technologies relies significantly on the form of plant and fuel used, where the post-combustion capture system was commonly considered to be low-cost technologies for gas-fired power plants. Absorption is the most advanced method of $\mathrm{CO}_{2}$ separation thanks to its high performance and low expense, while environmental risk concerns remain to be better established. The best choice for transporting $\mathrm{CO}_{2}$ would rely on a number of factors, including (a) the volume of $\mathrm{CO}_{2}$ to be transported; (b) the expected existence of the $\mathrm{CO}_{2}$ supply (e.g. power plants, steel and cement factories); (c) the distance between the $\mathrm{CO}_{2}$ source and the storage area; (d) onshore and offshore shipping and storage; (e) Typology of accessible transport facilities (i.e. road and rail networks, pipelines), and (f) trunks, ports for shipping). 
A pipeline is thought to be the most feasible option if vast quantities of $\mathrm{CO}_{2}$ are accessible for a long period and if a trunk of pipelines can be developed. A further benefit is the possible re-use of gas or oil pipelines. In the case of offshore storage, $\mathrm{CO}_{2}$ transport by tankers can be economically competitive due to the high capital costs involved in the deployment of submarine pipelines. The expenses of intermediate storage facilities and adequate loading for tankers will be discussed as ships are used as $\mathrm{CO}_{2}$ carriers. For the preservation of $\mathrm{CO}_{2}$, four primary forms of geological structures are considered: (a) Depleted oil and gas reservoirs; (b) the un-mining of coal beds; (c) freshwater aquifers, and (d) the basalts.

In the case of oil and gas reservoir mining, the technique already used for enhanced oil recovery (EOR) is proven and has been utilized for several years for natural sources of $\mathrm{CO}_{2}$ and mainly onshore. However, the economic feasibility of using captured $\mathrm{CO}_{2}$ from anthropogenic sources for EOR has not yet been fully demonstrated, mostly for offshore storage. The use of un-minable coal beds, eventually recovering methane from Enhanced Coal Bed Methane (ECBM) recovery, may be an option, but it will make the coal used for $\mathrm{CO}_{2}$ storage unavailable even if future mining technology and economic considerations make it commercially valuable. On the other hand, there is a growing interest in the storage of $\mathrm{CO}_{2}$ in saline aquifers due to their enormous potential for storage, and several projects are under development both onshore and offshore. Basalts contain an incredibly significant quantity of $\mathrm{CO}_{2}$ content to be set as carbonate minerals after a chemical reaction with the minerals of the host rocks. A variety of complexities, ranging from the need for an incredibly comprehensive knowledge of the stratigraphic composition of the basalts to a complete understanding of the chemical reaction, also hinder their use. Potential $\mathrm{CO}_{2}$ leakage is the main problem for geological storage and a robust monitoring system needs to be established. A variety of monitoring techniques have been identified in this paper to be implemented in compliance with the specific environmental requirements of the storage site. While technologies for capturing and storing $\mathrm{CO}_{2}$ exist, the total cost of utilizing current CCS procedures is still high and must be substantially reduced before it can be widely implemented. There are several barriers to CCS implementation that need to be resolved in the coming years, including the absence of a compelling business rationale for CCS expenditure and the lack of adequate economic opportunities to cover increased high capital and operational costs associated with CCS.

\section{Recommendation}

\subsection{Projects}

Engage with regional governments to promote the implementation of national policies to help to raise the pollution intensity of production, such as fossil-fuel power generation, through the usage of CCS. Its method may also help to classify. Potential CCS ventures to be used in the production process of the companies. Engage with the G20 to extend the G8 goal to become the "G20 priority. Engage with related government departments and/or partner organizations to find such large size, interconnected initiatives that could not have been established as part of the survey. Consult with project supporters and related partners to define any issues and approaches for its resolution for projects found through this phase. Engaging with the promoters of the currently planned 55 interconnected, commercial-scale projects to recognize clear holes and obstacles in the creation of their business case, taking into consideration their characteristics, including venue, Software type and selection of storage choices.

Engage with the promoters of 30 "linked" ventures to recognize any obstacles unique to their success as an "integrated" project and, together with other related partners, promote coordination and partnership in the production of their business case. Track the success of large-scale initiatives that are not fully interconnected to determine prospects for collaboration with other parties. Engage the related governments and initiative advocate to study and promote the construction of transport and storage

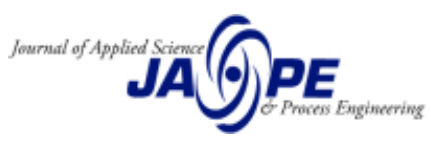


networks. An indication of that will be an agreement between the EU and the United Kingdom to establish a network for the North Sea area, despite the large volume of proposals promoting the storing of $\mathrm{CO}_{2}$ in the vicinity. Engage with project promoters and governments in areas that are historically underrepresented in CCS programs, such as Asia, China and South America, to recognize and grow a pipeline of CCS projects. Engage with plant operators, business groups, service suppliers and other partners in sectors that are historically underrepresented in CCS programs, e.g. cement, aluminium and iron/steel manufacturing, to promote the implementation of programs.

\subsection{Technology}

Explore the ability to reduce $\mathrm{CO}_{2}$ production costs by rising $\mathrm{CO}_{2}$ pollution. Percentage of capture for large size programs. Facilitate focused R\&D activities on a global scale, coordinated ventures Identified in the analysis. Encourage authorities to provide guidelines on the processing of $\mathrm{CO}_{2}$ to reach requirements. Regional $\mathrm{CO} 2$ reduction strategies for the area. Train stakeholders on the crucial reliance of all CCS initiatives on storage It's part of the CCS line. Educate policymakers and financial organizations on the risks of identifying and assessing A location for secure storage of $\mathrm{CO}_{2}$ is expected to be large and must be set up in preparation at the Identify and Evaluate stages. Educate governments and supporting agencies that CCS ventures would need financing; Government and storage help can require substantial expenditure to be paid and to note that the secure storage of $\mathrm{CO}_{2}$ is at the volumes needed for the output of $\mathrm{CO}_{2}$.

Engage with OEMs to establish capture, process and power plant technology to enable the development of interconnected ventures rather than project-only capture. Engage with policymakers and other supporting agencies to promote broad assessments aimed at locating possible storage sites in all regions where CCS would need to be implemented and ultimately introduced. Facilitate small-scale injection programs aimed at raising awareness of the ability of various geological structures to have safe $\mathrm{CO}_{2}$ trapping mechanisms. Acting with other primary stakeholders, promote the deployment of MMV on a commercial scale of EOR operations as a means of developing awareness on the secure storage of $\mathrm{CO}_{2}$ in geological formations.

\subsection{Economics of CCS}

Advise and foster understanding among funding agencies and other core stakeholders that CCS costs should remain high for FOAK plants and that incentives to minimize costs are likely to be minimal in the timeframe that CCS projects would continue to be introduced. sanctioned if the G8 timelines are to be achieved. Advise and educate key decision-makers that the only way to reduce the cost of CCS is through gaining knowledge and learnings from installing CCS technologies to multiple integrated projects at commercial scale in the near term and with ongoing R\&D funding to achieve far more substantial cost savings as a consequence of CCS technological advancements in the longer term. Engage private, distributed, infrastructure advocates described in this study to define possible cost savings opportunities across multi-user pipelines and traditional storage sites.

Integrated projects with commercial-scale proponents have been identified in this study to determine what assistance can be provided to overcome the likely storage barriers. Work with other key funding agencies such as industry groups, national governments and supranational institutions such as the G20, the World Bank and the Asian Development Bank to consider funding sources for CCS projects. Communicate to governments that funding from private equity and debt markets are highly unlikely for CCS projects and that because of this, significant public expenditures are highly likely to be required. Advocate for the adoption of a range of portfolio financing options such as fixed feed-in tariffs, TECs, tax incentives, accelerated depreciation and production tax credits. 


\subsection{Policies and legislation}

Study and, where applicable, recommend changes to international agreements that may regulate the transboundary transport of $\mathrm{CO}_{2}$, including the meanings of "waste" under the Protocol and "hazardous waste" under the law; Advise policymakers that legislative mechanisms ought to tolerate very long storage timeframes in order to accurately assign liabilities for leakage. Advise governments on amendments to existing legislation applicable to the CCS project cycle where time or other circumstances do not permit the development of integrated or dedicated CCS legal systems;

Evaluate policy and environmental policies and how they may be utilized to mandate (or at least make economically viable) the usage of CCS in existing or upgraded power plants and other GHG generating installations and undertakings; tax or other incentives could be needed to offset the costs associated with these requirements; Help establish and encourage CCS project-specific bestpractice legislative standards and model regulations (e.g. UK, USA, Japan and Australia) that can be adopted by countries seeking to support, accommodate and encourage CCS projects; Assist domestic legislators by providing examples of legislative reform initiatives from other jurisdictions that have already enacted CCS specific legislation to help promote and facilitate CCS projects, particularly in developing countries.

\subsection{Public acceptance}

Create a monitoring system to recognize and, in collaboration with others, ensure that key decision-makers embrace the growth and implementation of CCS as new technology and, more importantly, the initiatives described in this report. Inform stakeholders by periodically reviewing the status of CCS programs, regulations and laws, costs and R\&D innovations utilizing the details and structures gathered through this analysis as a basis.

Engage actively its leaders to create relationships to establish and exchange CCS knowledge. Engage jointly with governments at the strategic level to provide information and Advise CCS and its ability as one of the main strategic solutions to reduce the danger of climate change. Share this and other important CCS details regularly, either independently or in collaboration with other leading agencies such as the CSLF and the IEA GHG R\&D System, via a number of channels, including its platform, conferences and numerous business and policy fora. Engaging with commercial-scale advocates, interconnected initiatives described in this analysis to evaluate their public approval approaches and any assistance that may be needed to mitigate public opposition.

\section{Conclusion}

In conclusion, there will be a need to shift to a new energy economy that involves the use of low or zero-emission technologies such as CCS. The development of such technologies will take time and existing reserves of fossil fuels will continue to play an important role in creating the energy needed to drive societies. As such, society will face the prospect of having to deal with continually rising $\mathrm{CO}_{2}$ emission levels from the use of fossil fuels worldwide. Considering this, the application of CCS must be accelerated. This study describes developments in $\mathrm{CO}_{2}$ capture technologies, various options of precombustion and post-combustion $\mathrm{CO}_{2}$ capture processes and underground $\mathrm{CO}_{2}$ storage. The $\mathrm{CCS}$ technology is developing but not proven. Each of the options for $\mathrm{CO}_{2}$ capture, disposal and storage in closed or open reservoirs has some unresolved challenges. More attention is also required to be given to the development of cost-effective geoengineering approaches, which aim to accelerate the natural process of $\mathrm{CO}_{2}$ absorption in the biosphere, lithosphere and oceans. 


\section{Acknowledgements}

The authors would like to acknowledge the Faculty of Engineering, Universiti Malaysia Sarawak (UNIMAS), 94300 Kota Samarahan, Sarawak, Malaysia for the support.

\section{References}

[1] Boot-Hardford, M.E., Abanades, J.C., Anthony, E.J., Blunt, M.J., Brandani, S., Dowell, N.M., Fernandez, J.R., Ferrari, M.-C., Gross, R., Hallett, J.P., Haszeldine, R.S., Heptonstall, P., Lyngfelt, A., Makuch, Z., Mangano, E., Porter, R.T.J., Pourkashanian, M., Rochelle, G.T., Shah, N., Yao, J.G., Fennell, P.S. (2014) Carbon Capture and storage update. Energy \& Environmental Science 7(1), 130-189. https://doi.org/10.1039/C3EE42350F

[2] Offshore Engineers (2020) JOGMEC, JX, Petronas Testing CCS at Malaysian Gas Fields. Viewed on 17/11/2020. https://www.oedigital.com/news/476970-jogmec-jx-petronas-testing-ccs-at-malaysian-gasfields

[3] Anderson, S., Newell, R. (2004) Prospects for carbon capture and storage technologies. Annual Review of Environment and Resources 29(1), 109-142. https://doi.org/10.1146/annurev.energy.29.082703.145619

[4] Das, S., Kumar, J. (2012). Carbon capture and storage. International Journal of Scientific \& Engineering Research (7)10, 1385-1289. https://doi.org/10.14299/ijser.2016.10.006

[5] Abdallah, L., \& El-Shennawy, T. (2013). Reducing carbon dioxide emissions from electricity sector using smart electric grid applications. Journal of Engineering, 2013(845051), 1-9. https://doi.org/10.1155/2013/845051

[6] Smit, B., Park, A.-H.A., Gadikota, G. (2014) The grand challenges in carbon capture, utilization, and storage. Frontier of Energy Research 2(55), 1-3. https://doi.org/10.3389/fenrg.2014.00055

[7] Solomon S. (2007) Carbon dioxide storage: Geological security and environmental issues-Case study on the Sleipner Gas Field in Norway. Bellona Report, 1-126.

[8] Philbin, S.P., Wang, S.H.-M. (2019) Perspectives on the techno- economic analysis of carbon capture and storage. Journal of Technology Management and Innovation, 14(3), 3-17.

[9] Herzog, H. (2015). Carbon Dioxide Capture and Storage. In: Helm, D., Hepburn, C. The Economics and politics of climate change, Oxford Scholarship Online, 263-283. https://doi.org/10.1093/acprof:osobl/9780199573288.003.0013

[10] Sahimaa, O., Mattinen, M. K., Koskela, S., Salo, M., Sorvari, J., Myllymaa, T., Seppälä, J. (2017). Towards zero climate emissions, zero waste, and one planet living - Testing the applicability of three indicators in Finnish cities. Sustainable Production and Consumption. https://doi.org/10.1016/j.spc.2017.02.004

[11] Sreedhar, I., Nahar, T., Venugopal, A., \& Srinivas, B. (2017). Carbon capture by absorption-Path covered and ahead. Renewable and sustainable energy reviews, 76, 1080-1107. https://doi.org/10.1016/j.rser.2017.03.109

[12] Bhown, A. S., \& Freeman, B. C. (2011). Analysis and status of post-combustion carbon dioxide capture technologies. Environmental science \& technology, 45(20), 8624-8632. https://doi.org/10.1021/es104291d

[13] CQ Press. (2020). National Oceanic and Atmospheric Administration. In Federal Regulatory Guide. https://doi.org/10.4135/9781544377230.n58

[14] Knudsen, J. N., Jensen, J. N., Vilhelmsen, P. J., \& Biede, O. (2009). Experience with $\mathrm{CO}_{2}$ capture from coal flue gas in pilot-scale: Testing of different amine solvents. Energy Procedia, 1(1), 783-790. https://doi.org/10.1016/j.egypro.2009.01.104 
[15] Takamura, Y., Aoki, J., Uchida, S., \& Narita, S. (2001). Application of high-pressure swing adsorption process for improvement of $\mathrm{CO} 2$ recovery system from flue gas. The Canadian Journal of Chemical Engineering, 79(5), 812-816. https://doi.org/10.1002/cjce.5450790517

[16] Azar, C., Lindgren, K., Larson, E., \& Möllersten, K. (2006). Carbon capture and storage from fossil fuels and biomass-costs and potential role in stabilizing the atmosphere.Climatic change, 74(1), 47-79. https://doi.org/10.1007/s10584-005-3484-7

[17] Adánez, J., de Diego, L. F., García-Labiano, F., Gayán, P., Abad, A., \& Palacios, J. M. (2004). Selection of oxygen carriers for chemical-looping combustion. Energy \& Fuels, 18(2), 371-377. https://doi.org/10.1021/ef0301452

[18] Li, F., Luo, S., Sun, Z., Bao, X., \& Fan, L. S. (2011). Role of metal oxide support in redox reactions of iron oxide for chemical looping applications: experiments and density functional theory calculations. Energy \& environmental science, 4(9), 3661-3667. https://doi.org/10.1039/c1ee01325d

[19] Lyngfelt, A. (2015). Oxygen carriers for chemical-looping combustion. In Calcium and chemical looping technology for power generation and carbon dioxide (CO2) capture, 221-254. Woodhead Publishing. https://doi.org/10.1016/B978-0-85709-243-4.00011-2

[20] Erlach, B., Schmidt, M., \& Tsatsaronis, G. (2011). Comparison of carbon capture IGCC with precombustion decarbonisation and with chemical-looping combustion. Energy, 36(6), 3804-3815. https://doi.org/10.1016/j.energy.2010.08.038

[21] Riahi, K., Rubin, E. S., Taylor, M. R., Schrattenholzer, L., \& Hounshell, D. (2004). Technological learning for carbon capture and sequestration technologies. Energy economics, 26(4), 539-564. https://doi.org/10.1016/j.eneco.2004.04.024

[22] Yave, W., Car, A., Funari, S. S., Nunes, S. P., \& Peinemann, K. V. (2010). CO2-philic polymer membrane with extremely high separation performance. Macromolecules, 43(1), 326-333. https://doi.org/10.1021/ma901950u

[23] Brunetti, A., Scura, F., Barbieri, G., \& Drioli, E. (2010). Membrane technologies for CO2 separation. Journal of Membrane $\quad$ Science, 359(1-2), 115-125.. https://doi.org/10.1016/j.memsci.2009.11.040

[24] Bernardo, P., Drioli, E., \& Golemme, G. (2009). Membrane gas separation: a review/state of the art. Industrial \& engineering chemistry research, 48(10), 4638-4663. https://doi.org/10.1021/ie8019032

[25] Nohra, M., Woo, T. K., Alavi, S., \& Ripmeester, J. A. (2012). Molecular dynamics Gibbs free energy calculations for $\mathrm{CO} 2$ capture and storage in structure I clathrate hydrates in the presence of SO2, CH4, N2, and H2S impurities. The Journal of Chemical Thermodynamics,44(1), 5-12. https://doi.org/10.1016/j.jct.2011.08.025

[26] Tuinier, M. J., van Sint Annaland, M., Kramer, G. J., \& Kuipers, J. A. M. (2010). Cryogenic CO2 capture using dynamically operated packed beds. Chemical Engineering Science,65(1), 114-119. https://doi.org/10.1016/j.ces.2009.01.055

[27] Hoeger, C., Bence, C., Burt, S. S., Baxter, A., \& Baxter, L. (2010). Cryogenic $\mathrm{CO}_{2}$ capture for improved efficiency at reduced cost. AIChE Annual Meeting, Conference Proceedings.

[28] Göttlicher, G., \& Pruschek, R. (1997). Comparison of $\mathrm{CO}_{2}$ removal systems for fossil-fuelled power plant processes. Energy Conversion and Management,38, S173-S178.. https://oi.org/10.1016/s01968904(96)00265-8

[29] Leung, D. Y., Caramanna, G., \& Maroto-Valer, M. M. (2014). An overview of current status of carbon dioxide capture and storage technologies. Renewable and Sustainable Energy Reviews, 39, 426-443.. https://doi.org/10.1016/j.rser.2014.07.093

[30] Zhang, Y., Lu, X., \& Ji, X. (2019). Carbon Dioxide Capture. Deep Eutectic Solvents: Synthesis, Properties, and Applications, 297-319. https://doi.org/10.1002/9783527818488.ch15

[31] Pires, J. C. M., Martins, F. G., Alvim-Ferraz, M. C. M., \& Simões, M. (2011). Recent developments on carbon capture and storage: an overview. Chemical engineering research and design, 89(9), 1446-1460. https://doi.org/10.1016/j.cherd.2011.01.028 
[32] Shackley, S., Reiner, D., Upham, P., de Coninck, H., Sigurthorsson, G., \& Anderson, J. (2009). The acceptability of $\mathrm{CO}_{2}$ capture and storage (CCS) in Europe: An assessment of the key determining factors: Part 2. The social acceptability of CCS and the wider impacts and repercussions of its implementation. International Journal of Greenhouse Gas Control,3(3), 344-356. https://doi.org/10.1016/j.ijggc.2008.09.004

[33] Minchener, A. J. (2014). Gasification based CCS challenges and opportunities for China. Fuel, 116, 904909. https://doi.org/10.1016/j.fuel.2013.02.046

[34] Van Alphen, K., tot Voorst, Q. V. V., Hekkert, M. P., \& Smits, R. E. (2007). Societal acceptance of carbon capture and storage technologies. Energy $\quad$ Policy, 35(8), https://doi.org/10.1016/j.enpol.2007.03.006

[35] Araújo, O. de Q. F., \& de Medeiros, J. L. (2017). Carbon capture and storage technologies: present scenario and drivers of innovation. Current Opinion in Chemical Engineering, 17, $22-34$. https://doi.org/10.1016/j.coche.2017.05.004 